\title{
Strenghtening Students' Characters Education through Legal Awareness Policies Analysis
}

\author{
Akmal Akmal \\ Prodi Pendidikan Pancasila dan Kewarganegaraan \\ Universitas Negeri Padang \\ Padang, Indonesia \\ akmalmarlis@gmail.com
}

\begin{abstract}
The objectives of the research are: (1) to map the condition of character education of junior high school students, (2) to know the effectiveness of character education policy implementation through legal awareness, and (3) to find the effectiveness model of strengthening character education based on legal awareness in SMP. Qualitative and quantitative research methodology, student population of SMP Kabupaten Pesisir Selatan is 700 students. Qualitative and quantitative analysis techniques. Result of research: The condition of character education mapping of students is moderate. For the implementation of the character education policy has not been effective and based on legal awareness, the causes among other things, the character education policy is too forced the program, less awakened from self-awareness of the students so that students in the program are less serious. The effectiveness model for strengthening character education based on legal awareness needs to be adjusted to the condition of the learning process of students at school and outside school. Supervision actions by local government and school need to involve parents, ninik mamak, religious figures, and intelligent outposts that exist in the school environment. From the aspects of: (1) the substance of the character education program, (2) the structure of the regulation made: the structure of character education policy that is made there between overlapping regulations.
\end{abstract}

Keywords-legal awareness policy analysis; student character education

\section{INTRODUCTION}

Characters' education is a children characters' building, characterized relgiousness, nationality, integrity, honesty and mutual cooperation Character education is a building of character for human children, characterized by: religious, nationality, integrity, honesty and gotong royong [1]. Education is aimed to build to a good character such as goodnatured, self-directed, self-conceptual character. In the Law No.20 of 2003 and K-13 it is said that education is an effort to develop the potential of students themselves into a whole and intact human [2]. Character education is an effective means of promoting both student social, moral, emotional development and academic achievement [3].

The challenge faced by young Indonesians in junior high school is the lack of character education, which is demonstrated by lack of understanding to applicable laws and awareness of human rights, so that they are disobedient, inconsistent, often breaking collective agreements, and most dangerously easy to have some unlawful thoughts such as violence, anti-religion, radicalism, terrorism, and ideologies that conflict with national law, religion and customary law as the value of local wisdom.

Character education policy cannot be separated from various problems and the challenges that faced by the Indonesian [4]. Indonesia's educational goals are not only intellectually intelligent, but also intelligent spiritual, emotional and personable. The character of the Indonesian nation is the character owned by Indonesian citizens in the form of actions that are considered as a virtues based on the prevailing values in Indonesia [5] .

To support the character education program, the regional government of Pesisir Selatan Regency has issued various policies, among others, to make regulations, such as RPJM and RPKD policies, local regulations and related WTO policies. These policies, in fact, have not been effective yet, as there are still a variety of student behaviors that deviate from the goals of character education at the level of religious values, integrity, nationalism, togetherness, and gentong royong. This shows the behavior of junior high school students in Pesisir Selatan Regency seen in the following Table I:

TABLE I. THE REALITIES OF AWARENESS OF LEGAL EDUCATION THROUGH CHARACTER EDUCATION OF STUDENTS AT SMP PESISIR SELATAN DISTRICT

\begin{tabular}{|c|l|l|lr|c|}
\hline No & \multicolumn{1}{|c|}{$\begin{array}{c}\text { Junior High } \\
\text { School Group }\end{array}$} & \multicolumn{1}{|c|}{$\begin{array}{c}\text { Beach of Conduct } \\
\text { Form }\end{array}$} & \multicolumn{2}{|c|}{ Sanction } & Amount \\
\hline 1 & Group A & $\begin{array}{l}\text { Toward teachers, } \\
\text { friends, and school }\end{array}$ & $\begin{array}{l}\text { Letter } \\
\text { agreement }\end{array}$ & 36 \\
\hline 2 & Group B & $\begin{array}{l}\text { Toward teachers, } \\
\text { friends, and school }\end{array}$ & $\begin{array}{l}\text { Letter } \\
\text { agreement of } \\
\text { move out }\end{array}$ & 83 \\
\hline 3 & Group C & $\begin{array}{l}\text { Toward teachers, } \\
\text { friends, and school }\end{array}$ & $\begin{array}{l}\text { Letter of } \\
\text { agreement, move } \\
\text { out and expelled }\end{array}$ & 96 \\
\hline
\end{tabular}

a. Source: Pengelohan Data Education Office Kab. Pessel and Akriditasi Board of Education Service of Research objectives: West Sumatera Province 2016

- Finding the condition and level of understanding of character education by junior high school students in Pesisir Selatan Regency? 
- Knowing the effectiveness of the implementation of education policy character of the Regional Government in South Coastal District Pesisir Selatan

- Looking for the effectiveness model of strengthening character education in SMP Pesisir Selatan District.

\section{THEORETICAL}

The Collaborative for Academic, Social, and Emotional Learning (CASEL), aninternational group of educators, researchers, practitioners, and policy makers (see www.casel.org), has drawn from an extensive empirical literature to identify teachable skills essential for educating students for sound character and seeing themselves and their learning as positive resources for their families, schools, workplaces, and communities [6].

TABLE II. TAXONOMY OF CHARACTER EDUCATION PROGRAMS

\begin{tabular}{|l|l|}
\hline \multicolumn{1}{|c|}{ Type } & \multicolumn{1}{|c|}{ Major Pedagogical Approach } \\
\hline $\begin{array}{l}\text { Moral reasoning- } \\
\text { Cognitive } \\
\text { development }\end{array}$ & $\begin{array}{l}\text { Discussion of moral dilemmas facilitates student } \\
\text { development of moral reasoning capacities }\end{array}$ \\
\hline $\begin{array}{l}\text { Moral education- } \\
\text { Virtue }\end{array}$ & $\begin{array}{l}\text { Academic content (literature, history) used to } \\
\text { teach about moral traditions to facilitate moral } \\
\text { habits and internal moral qualities (virtues) }\end{array}$ \\
\hline Life skills education & $\begin{array}{l}\text { Practical skills (communication) and positive } \\
\text { social attitude (self-esteem) stressed }\end{array}$ \\
\hline Service-learning & $\begin{array}{l}\text { "Hands-on" experiences of community service } \\
\text { integrated into the curriculum }\end{array}$ \\
\hline $\begin{array}{l}\text { Citizenship training. } \\
\text { Civics education }\end{array}$ & $\begin{array}{l}\text { American civic values taught as a preparation for } \\
\text { future citizenship }\end{array}$ \\
\hline Caring community & $\begin{array}{l}\text { Caring relationships fostered in the classroom } \\
\text { and school }\end{array}$ \\
\hline $\begin{array}{l}\text { Health education- } \\
\text { Drug, pregnancy, and } \\
\text { violence prevention }\end{array}$ & $\begin{array}{l}\text { Program-oriented approach used to prevent } \\
\text { unhealthy/ antisocial behaviors }\end{array}$ \\
\hline $\begin{array}{l}\text { Conflict resolution- } \\
\text { Peer mediation }\end{array}$ & $\begin{array}{l}\text { Students trained to mediate peer conflicts as a } \\
\text { means of developing constructive conflict } \\
\text { resolution skills }\end{array}$ \\
\hline $\begin{array}{l}\text { Ethics Moral } \\
\text { philosophy }\end{array}$ & Ethics of morality explicitly taught \\
\hline Religious education & $\begin{array}{l}\text { Character education taught in the context of a } \\
\text { faith tradition, justifying morality from a } \\
\text { transcendent sourc }\end{array}$ \\
\hline
\end{tabular}

\section{Strengthening Character Education}

Picture . Character Value In Each Education Unit

$\begin{array}{cc}\text { Intellectual Exercise } & \text { Moral Exercise } \\ \text { Intelligent } & \text { Honesty } \\ \text { Creativity } & \text { Responsibility } \\ \text { Physical Exercise } & \text { Mental Exercise } \\ \text { (KINESTETIK) } & \text { Empathy } \\ \text { Clean, Healthy, Attractive } & \text { Creativity }\end{array}$

In recent developments as an effort to make character education easy to be implemented, the character values for the subjects have been identified: Religious, Honesty, Intelligence, Reliability, Democracy, and Concern. While the value of the main characters Subject: Nationalist, Compliance with social rules, Respecting diversity, Awareness of rights and obligations of self and others, Responsible, logical, critical, creative, and innovative thinking, and Independence [1]. Instead of integrating character education with other subjects, character education can be provided through non-formal learning [8]. Education for character requires practical experience; of citizens learning through habit rather than simply through reasoning, and through this training they can come to recognize how they should live and are able to live in such a way [9].

According to Bung Hatta, character education of the people is: independent, know the rights and obligations, willing to take responsibility [10]. If the values of the character has become the character of the Indonesian nation, then our nation will become a nation that is advanced and prosperous. Because it has met the characteristics of a developed and modern nation [11], Characters do not automatically appear in people at the time they are born and needs a long process through parenting and education [12].

\section{METHOD}

The population in the study were all pioneering schools of character education and non pioneering junior high school in the Education and Culture of Pesisir Selatan Regency and various forms of character education policy conducted by the regional government. Selection of sample schools is based on the representation of school pioneering character education. Namely SMP Negeri 1 Bayang and SMP Negeri 1 Painan, and non-pilot schools. The sample for the students' understanding questionnaire on character education was obtained from as many as 700 students. the education of regional characters. Data that have been obtained by quantitative and qualitative analysis of the students' character education knowledge [13]. Then seen the relation of effectiveness of character education of student. Followed by FGD to find model and improvement of education policy of regional character of Pesisir Selatan Regency.

\section{RESULT AND DISCUSSION}

The research has found out about the condition and level of understanding of character education by junior high school students in terms of (1) knowledge (2) attitude (3) skill (4). Data about the variables regarding the condition and level of understanding of character education by junior high school students are given to students amounting to 700 students.

The Effectiveness of the Character Education Policy Implementation by the Local Government in South Coastal High School Pesisir District can be seen through various policies in the form of regulation made to promote and enforce the character education. The regulation is shown in the following documents:

- RPJM Pemda Pesisir Selatan regency as stipulated in Local Regulation No. 3 of 2016 on regional RPJM year 2016-2021

- RKP Pemda Pesisir Selatan, and some other legal products in order to support the character education program. 
- Policies in the form of regional regulations, regulations and decisions of the Bupati, Head of Education and Culture, Headmaster Decision

The results of interviews with the Head of Education and Culture, Headmaster that the types and forms of policies taken for the creation of character education are as follows:

- For religious values: dawn activities in congregation, Zohur prayers in congregation at school, Magrib Koran

- For the value of nationality: ceremonial activities, scouts, visiting the tomb of the hero, making a description of the character of national figures

- For the value of integrity: sports activities and competitions, art, saint, papers, customary speech

- For the value of honesty: activities such as honesty canteen making, teachers make home visits to monitor student activities

- For the value of togetherness / goro: school hygiene competition activities, create environmental groups,

Based on survey results, the effectiveness of policies that have been done Based on the level of respondents' achievement of character education indicators (religious, nationality, integrity, honesty and togetherness/gotong royong) then the tendency of effectiveness level is classified as less effective. From the results of analysis data can be explained: 564 $(80.57 \%)$ students say that it is less effective.

Based on interviews with the students, the tendency of students to say that the cause of the effectiveness of the education policy is too forced to the character of the program, less awakened from self-awareness of students. Factors inhibiting Character Education Policy

In discussing about the inhibiting factors of educational policy of the learner's character, there is a very close relationship between law enforcement, community, supporting facilities, culture and existing regulations. Soerjono Soekanto said factors affecting character education or inhibiting the awareness of educational policy of the learner characters, namely: the legal factor itself, which is limited to the regulation of the region and school (School Code of Conduct), law enforcement factors, ie the parties that form and apply the law, the factor of facilities or facilities, which supports character education, the factor of society, that is the environment in which the law is applied or applied, and the cultural factor, that is, the work, creativity, and sense based on human initiative in the social life. Research result

\section{A. Its own legal factors, which are limited to regional and school regulations (School Rules of Conduct).}

It concerns about: structure, substance, and legal culture. Based on the above table, from 700 participants who circulated the evaluation questionnaire obtained information as many as 475 people $(67.85 \%)$ students have a good perception of regional regulations and rules of school discipline in terms of substance, structure, and culture of legal compliance. Based on follow-up interviews that they are less involved in making school rules.

\section{B. Law enforcement factors, namely the parties that make up and apply the law.}

Based on the above table, from 700 participants who circulated the evaluation questionnaire obtained information as many as 447 people $(63.85 \%)$ students say character education (orderliness) is less consistent by party penegka rules. Based on the continued interview that the tendency is less consistern on the rules of a mild penalty.

\section{Factors of facilities or facilities, which support character education.}

Based on the above table, of the 700 participants who circulated the evaluation questionnaire obtained information as many as 595 people $(84.99 \%)$ students said there is availability of school facilities and facilities in support of character education in schools.

Community factors, ie the environment in which students are located. (parents, school committee, community environment). Based on the above table, of the 700 participants who circulated the evaluation questionnaire obtained 355 people $(50,71 \%)$ of the students said less support parent school committee and school community environment in character education at school. Meneurut students often occur omission of the act against the law by students.

Cultural factors, in this research is, how far the habits in society and become a culture so that the barrier in building character education students.

Based on the above table, of the 700 participants who circulated the evaluation questionnaire obtained information as many as 355 people $(50.71 \%)$ students said culture is not as an obstacle to the education of student character in school.

Finding the Effectiveness Model for Strengthening Character Education for South Coast Pupil Students Based on the results of Focus Group Disscusion (FGD), involving Satpol PP related parties, and Social Affairs of the Regional Government of South Pesisir Regency [14].

- The substance of the character education program: for the program that has been implemented the material needs to adjust to the needs of the students, the learning approach is still teaching has not internalized or instilled character education, such as modeling the model, story, flm / video about the values characters that can be replicated. There are some character values that students can take. Methods of lectures received by student make students bored, the students suggested that there is a role play, so students participate in the character's education

- Structure of regulation made: the structure of character education policy made between overlapping regulations, policy makers are still racing with the number of programs, not seeing the benefits, impacts, results, and benefits as the program (outcome, impact, and benefit) for students or learners 


\section{CONCLUSION}

Based on the findings and discussion there are several conclusions:

\section{A. Condition and level of understanding of character education by junior high school students in Pesisir Selatan Regency}

Based on the results of the analysis of research findings, in terms of knowledge tendency classified as moderate, for the overall attitude seen from the level of achievement of respondents tend to be good, for the students' skills to character education is quite good. The character education profile of the students can be the basis for the character education policy. Character education policies that were made before and now are not based on the student profile, so this policy has not received the full support of the students.

\section{B. The effectiveness of the implementation of character education policy by the local government and schools in the students of Pesisir Selatan Regency}

Based on the research findings data, the implementation of character education policy has not been effective, among other things, the policy of character education is too forced to the program, less awakened from self-awareness of the students so that the students in the program are less serious.

\section{The effectiveness model of strengthening character education for South Coast Pesisir students}

Based on the effectiveness model data, still need to adjust to the condition of the learning process of students in school and outside school. Includes other factors that are internal and external conditions of learners. Supervision actions by the local government and the school need to involve parents, ninik mamak, religious leaders, and intelligent outlaws that exist in the school environment.

\section{Suggestion from this research}

- The character education profile of the students can be the basis for the character education policy. The character education policy created should be based on the student profile, so policy gets full support. Implementing a character education policy to be effective requires attention to the student's substance, structure, and culture. So awakened awareness of student self-education education. In the implementation of character education policy needs to involve traditional leaders, religious leaders, intelligent outrigger, bundo candidate in the school environment.
- Based on the effectiveness model data, still need to adjust to the internal and external conditions of learners. The conduct of supervisory measures undertaken by the local government and the school needs to be refined and improved. This model needs to be piloted, limited to pioneering and non-pilot schools.

\section{ACKNOWLEDGEMENTS}

If any, should be placed before the references section without numbering.

\section{REFERENCES}

[1] Kemdikbud, Konsep dan PedomanPenguatan Pendidikan Karakter. Jakarta: Kemdikbud. RI, 2015.

[2] Undang-undang Republik Indonesia No 20 tahun 2003

[3] M.W. Berkowitz and M.C. Bier, "Research-Based Character Education," The ANNALS of the American Academy of Political and Social Science, vol. 591, no. 1, pp. 72-85, 2004.

[4] Y. Hartono, S. Haryanto, and Asrowi, "Character Education in the Perspective of Humanistic Theory: A Case Study in Indonesia," EDUCARE: International Journal for Educational Studies, vol. 10, no. 2 , pp. 95-108, 2018

[5] P. Fitriyani and L.J. Bing, "Conceptual Analysis of Characer Education with Integrated Quality Insight in Indonesia," In International Colloquium: Opportunities and Challenges on Education Management in 21st Century (pp. 33-42). Htayai: Hatyai University, 2018.

[6] M.J. Elias, "Social-emotional and character development and academics as a dual focus of educational policy," Educational Policy, vol. 23, no. 6, pp. 831-846, 2009.

[7] R.W. Howard, M.W. Berkowitz, and E.F. Schaeffer, Politics of Character Education. Educational Policy, vpl. 18, no.1, 188-215, 2004.

[8] S.Y. Park, "Clarifying the Characteristics and Exploring the Collaboration of Citizenship and Character Education in South Korea," Journal of Social Science Education, vol. 16, no. 3, 22-28, 2017.

[9] B. Kisby, "Ben Kisby ' Politics is ethics done in public ': Exploring Linkages and Disjunctions between Citizenship Education and Character Education in England," Journal of Social Science Education, vol. 16, no. $3,8-21,2017$

[10] R. Bagun, Seratus Tahun Bung Hatta. Jakarta: Penerbit Buku Kompas, 2002.

[11] O. Zamroni, Persepsi Mahasisw terhadap Faktor-faktor yang mempengaruhi indenpendensi penampilan Akutansi Publik, 2006.

[12] D. Saripudin and K. Komalasari, "Living Values Education in School Habituation Program and Its Eff ect on Student Character Development," New Educational Review, vol. 39, no. 1, 107-118, 2015.

[13] J.W. Creswell and V.L.P. Clark, "Designing and conducting mixed methods research," Sage publications, 2017

[14] BPS, Pesisir Selatan dalamAngka 2017, Painan: Badan Pusat StatistikKabupatenPesisir Selatan, 2017. 